\title{
The casual academic workforce and labour market segmentation in Australia
}

Robyn May ${ }^{1}$, David Peetz and Glenda Strachan ${ }^{2}$

Griffith University

Robyn.May@griffithuni.edu.au

This paper may show minor differences to final printed version.

\footnotetext{
${ }^{1}$ Robyn May is an APAl scholarship holder on the ARC Linkage project: Gender and Employment Equity: Strategies for advancement in Australian Universities, 2009-2012 LP0991191.

${ }^{2}$ Professor David Peetz and Professor Glenda Strachan are both Chief Investigators on the ARC Linkage Project and all the authors are members of the Centre for Work Organisation and Wellbeing at Griffith University. The views expressed herein are those of the authors and are not necessarily those of the Australian Research Council.
} 


\section{The casual academic workforce and labour market segmentation in Australia}

\section{Abstract}

Teaching in Australian universities is performed by two groups of academic staff, defined by the nature of the employment contract. While permanent academic staff are engaged in teaching and research, a growing group of hourly-paid or casual employees deliver teaching services. This article explores some key dimensions of the work and aspirations of these casual academic staff, including levels of access to job and career supports, and career and job satisfaction. The 2011 Work and Careers in Australian Universities survey of staff in 19 universities provides data from more than 3,000 casual academic staff. Three related issues are investigated: the characteristics of labour supply in the casual academic labour force; the key defining boundaries of labour segmentation; and barriers between casual and permanent academic employment. A typology of casual academic staff is proposed. In particular, gender, type of university, and discipline are investigated to examine if these have an impact on the various measures of career opportunity, job satisfaction, and the incidence of the 'frustrated academic'. The research reveals that the casual academic labour market is not integrated with the permanent academic labour market and that discipline is a key determinant of the level of 'frustration' of casual academic staff.

Keywords: casual work, universities, segmented labour markets 


\section{The casual academic workforce and labour market segmentation in Australia}

\section{Introduction}

The phenomenon of casual (or temporary) employment is widespread in the Australian labour market. This paper investigates one specific type of casual employment in one industry, universities, where in the second decade of the twenty-first century casual staff deliver a significant proportion of the front-line operations of universities - teaching. Historically, through most of the twentieth century, university employment for academic staff followed a model strongly resembling an industry-wide internal labour market offering permanent employment. Academics entered at a junior level and gradually rose through the ranks in one or a number of universities. The growth of casual employment to deliver a proportion of the teaching changes this picture. There is a lack of clarity in the terminology used within universities and by staff themselves to refer to this group staff who are variously called 'casuals', 'sessionals' or 'teaching associates'. For precisionin this article we refer to the hourly paid staff who teach in universities as casual academic staff. Their counterparts, the academic staff who receive a regular salary with access to leave entitlements, we refer to as permanent academic staff, regardless of whether they are and are in on-going employment or on a fixed-term contract.

This article focuses on the casual academic staff who teach - that is, lecture or deliver tutorials or undertake associated teaching work. What sort of labour market do casual academic staff experience? We seek to answer three related key questions about casual academic staff. Firstly, what are the characteristics of labour supply in the casual academic labour force? Second, is segmentation manifested there and, if so, what are the key defining 
boundaries of segments, if any, in that labour market (Kimber, 2003)? Third, if there are barriers between casual and permanent academic employment, how strong are they: or, to put it another way, how frustrated are casuals in this labour force regarding their prospects for progression?

These are questions to which answers are limited. Poor data collection and reporting of casual academic staff numbers in the past and the diversity of this workforce has meant that little has been known about who or how many they are (Hugo, 2008; Coates \& Goedegeburre, 2010). This limited information remains despite arguments about their importance for the university sector particularly with the ageing of the permanent academic workforce, with many senior academics set to retire over the next decade (Hugo, 2008). At the same time there is an acknowledged need for urgent strategic workforce planning, funding pressures and increased volatility in income sources mean universities are under greater pressure to do more with less, unable to plan for the longer term.

\section{Background}

Casual academic employment in Australia has its origins in a 1980 decision of the Academic Salaries Tribunal that was required to grapple with the distinction between part-time and fractional time academic staff, and the variety of rates of pay and practices in the sector at that time. The Tribunal established a formula determining the rate of payment for each hour of face-to-face teaching, which included payment for associated preparation, marking, administration, and student consultation. The same formulation remains today, although marking is generally paid separately. In 1980 casual academic staff were seen as predominantly delivering specialist lectures, often bringing industry knowledge into the university. However, casual academic staff numbers have grown substantially. Table 1, using 
the only longitudinal data source of casual academic employment, collected by the federal government department responsible for oversight of universities, shows how full time equivalent (FTE) casual academic employment has more than tripled since 1990, compared with a much lower rate of growth in permanent (continuing and fixed-term) academic employment. The FTE measure, which is an attempt to equate casual work hours into that of a full time academic position, in accordance with a pre-set formula, is widely acknowledged to understate the full extent of casual employment (Percy et al., 2008). Using this data, over one-fifth of the FTE academic staff are employed on a casual basis. The measure understates the actual number of staff involved, as many work the equivalent of part time hours, promoting a lack of understanding about the size and role of the group and ultimately reinforcing the invisibility of the casual academic workforce.

\section{Table 1 here}

How the mass transformation of academic work, from secure and autonomous to insecure and invisible, took place, sits in a wider neo-liberal context that is both local and international. Since the Dawkins reforms of the late 1980s which created a unitary system of 37 public universities, Australia's universities have in many ways been at the forefront of the neoliberal experiment. The outcome of New Public Management (Hood 1991) has been the 'enterprise university', characterised by a new executive power, devolved budgeting, increased flexibility in staffing and a decline in collegiality (Marginson and Considine, 2000:9-10). The changes, sharpened by reductions in university funding, particularly under the Howard Coalition Government, 1996-2007, forced universities to be reliant on more volatile sources of income. Academic staff are experiencing workload pressures, are an 
ageing cohort, yet at the same time entrance to the profession is difficult, and less straightforward than in the past (Hugo 2008; Bradley 2009).

Internationally, there is evidence of insecure academic employment becoming an entrenched feature of comparator nations such as the UK, Canada and the USA, despite there being institutional differences (Bryson \& Blackwell 2006; Gappa \& Leslie 1993; Rajagopal \& Lin 1996; Robinson 2006). Over half the academic staff employed in the UK are employed on temporary contracts (Bryson \& Blackwell 2006) and similar proportions are employed parttime in Canada (Dobbie \& Robinson 2008). In the USA approximately half of all faculty work part-time and the majority of academic staff are not on 'tenure track' (Slaughter \& Rhoades 2004; Curtis \& Jacobe 2006) a trend described as 'the ongoing transformation of the profession into a majority of contingent [temporary] employees' (Schuster \& Finkelstein, 2006:5)

Dual or segmented labour market theory may provide a means of examining developments in the academic workforce in Australia's universities (Doeringer \& Piore 1971). The features of continuing academic employment such as job security, limited and controlled entry, career progression and on the job training conform to the notions of an internal labour market (Grimshaw, Ward, Rubery \& Benyon, 2001:27). These features, although industry rather than firm specific, give academic work a particular character and are strongly held notions of academe (Torens 1993).

Another distinctive feature of academia is the influence of academic discipline as both an organising base and social framework (Becher 1994). A number of American and Canadian studies have used segmented labour markets theory to examine the growth in insecure academic employment in those countries (Rosenblum \& Rosenblum 1997; Bauder 2006; 
Roemer \& Schnitz 1982). Bauder's (2006:231) discipline specific case study in Canada found that academia was subject to segmentation because it operated as a separate labour market, was internally segmented, and competition only existed within, not between, segments. Other studies have used segmented labour markets theory to examine the influence of academic discipline, gender and institutional type (Finnegan 1993; Moore, Acosta, Perry \& Edwards 2010). The theory can also offer a frame for understanding the divisions within the casual academic labour market although this is a complex operation and 'the task of disentangling the forces at work in particular labour markets is of course largely empirical' (Peck 1996:75).

In Australia casual academic staff have been described as, 'marginalised educational outworkers', (Blackmore 2002:433), 'the lost tribe', (Brand 2013) and 'the proletariat of the academic profession' (Percy et al. 2008:2). Aside from the problems associated with employment insecurity, surveys and case studies of casual staff have uncovered issues such as the lack of access to basic facilities such as a desk and a computer, exclusion from collegial forums, high administrative burdens, feelings of isolation, and poor communication from employers as common concerns (Brown, Goodman \& Yasukawa 2006; Churchman 2005; Gottschalk \& McEachern 2007; Junor 2004).

\section{Method}

During semester 2 of 2011, as part of the Work and Careers in Australian Universities (WCAU) survey, casual academic staff in 19 universities were invited to participate in an online survey investigating conditions of work, motivations for casual work, access to a range of job and career supports, job and career satisfaction, career intentions and the impacts of work and family. The survey instrument was developed to especially reflect the employment 
conditions of casual academic staff and the concerns raised in the academic literature. In all, 3160 casual academics responded to the survey, a 13.3 per cent response rate. The response rate, whilst lower than that for the academic staff survey (35 per cent) and professional/general staff survey (32 per cent) is consistent with casual workers' lower response rates in other surveys (see: Junor 2004; Morehead, Steele, Alexander, Stephen \& Duffin 1997). The response rates varied by university type as shown in Table 2. The four university types described are based on Marginson and Considine's (2000:189) typology which categorises universities by their stage of development and is elaborated in Appendix 1. The survey was over-represented by casual academics working at Sandstone Universities, who form a greater proportion of the casual sample and had a higher response rate.

\section{Table 2 here}

The survey questions for casual academic staff sought to capture two sets of data. One set related to the objective experience of casual academic employment, and whether a range of activities were included in the workload of a casual academic staff member, and whether these were undertaken on a paid or unpaid basis. These included activities such as marking, induction, professional development, collegial activities such as attending staff meetings, and the provision of research support. Unpaid activities have been noted as a major source of concern for casual teaching staff.

The second set of data related to questions about casual academics' sources of income, career intentions, motivations, orientations and employment mode preferences. These data sought to determine the proportions of casual academic staff that were wholly reliant on their casual work for their income, and separate to that, the proportions of staff that sought an academic 
career. Earlier research suggested that the majority of casual teaching staff would prefer more secure employment (Gottschalk \& McEachern 2007; Junor 2004). Despite this, questions have persisted over the motivations of casual academic staff and their suitability for future academic positions (Hugo 2008; Coates \& Goedegebuure 2010). Data were analysed using SPSS.

\section{Findings}

The results of the WCAU survey indicate that casually employed academic staff account for approximately half the academic workforce in Australia, on a headcount basis. This is based on the population data provided by each university in our study, as shown in Table 2. Headcount estimates of the proportions of academic staff employed on a casual basis have not been calculated previously, due to a paucity of data on the casual academic workforce and poor record keeping on the part of universities. This lack of information has contributed to a lack of understanding across the sector of the actual number of casual academic employees. The WCAU data highlights the extent to which the university sector is casualised. Across the Australian labour force approximately 24 per cent of workers are employed on a casual basis, a figure that has been steady for the past decade (ABS 2011). By comparison, 49 per cent of all academic staff (on a headcount basis), and 53 per cent of all teaching and research academic staff (this excludes research only/research intensive academic staff) are employed on a casual basis. We present more detailed breakdowns later, when outlining the main forms of segmentation in the market, but first we look at the main features of casual labour supply. 


\section{Characteristics of labour supply}

The WCAU survey provides a picture of the casual academic workforce and allows comparison with the permanent academic workforce in order to explore similarities and differences. Table 3, using results from both the academic staff survey and the casual academic staff survey, shows that casual academic staff are more likely to be female than their permanent academic colleagues. They are also substantially younger.

\section{Table 3 here}

Figure 1 displays the age profile for casual academic staff against that for permanent academic staff, by gender, using the WCAU survey results. The median age of casual academics, at 36, is 10 years less than permanent academics. In the Australian workforce as a whole, casuals are also younger than permanents, though academics are older and the difference is not as large: the mean age of casuals nationally is approximately 33 years, six years less than the average of 39 for permanent employees (ABS 2012). The much younger age profile of the casual academic workforce suggests, at first glance, that it may be an entry level issue - an academic workforce in waiting. But that would not take account of other features of the casual labour market.

\section{Figure 1 here}

Respondents were asked about their main source of income, and for the largest group it was casual employment itself. Women were slightly more likely than men to be reliant on it: 37 
per cent of women depended on their casual employment compared to 35 per cent of men. Men (29 per cent) were more likely than women ( 24 per cent) to be reliant on a scholarship. Men were more likely to be reliant on an income from outside the university sector, and much more likely to be reliant on a pension. Women reported much higher levels than men of dependence on another family member/partner as their main source of income: 12 per cent of women said they depended on family/partner as their main source of income compared with only five per cent of men.

\section{Do casual academic staff want permanent academic work?}

The diversity of motivation and orientation amongst insecurely employed academic staff has been the subject of some discussion in the international literature (Gappa \& Leslie 1993; Husbands \& Davies 2000; Rajagopal \& Lin 1996). Typologies for Australia have been developed by Junor (2004), Gottschalk and McEachern (2007) and Coates and Goedegebuure (2010). To analyse the WCAU data we use a comprehensive and mutually exclusive fourpart typology to synthesise the WCAU survey results, based on answers to questions about main sources of income, qualifications, and 'where would you like to be in five years time'. The typology in Table 4 categorises respondents according to their motivations and orientations towards casual academic employment as either academic, external to university sector, casual by choice, and retiree.

\section{Table 4 here}

The categorisation provides an important tool for further analysis of the survey data. It reveals that the majority of respondents are seeking a more secure academic position. Further, the findings show that women and men have similar aspirations and orientations. For the vast majority of respondents casual employment is a temporary staging post to either more secure 
academic employment, or work outside of the university sector. Only a small proportion actively prefers casual status as an ongoing situation. For those 56 per cent of respondents who are hoping for more secure academic employment, their experience of casual academic employment, and the support, training and development they receive in this role, is critical to their future career plans.

\section{Recruitment, induction and integration}

If casual academic employment was entry into the internal academic labour market, then entry procedures would be formalised and merit-based, progression above entry level would likewise be formalised and merit-based and this entry level would be closely integrated into the activities of the organisation. We do not fully test all of these ideas, but we test some. It is noteworthy that responses to the survey question, 'how did you obtain your current casual position', found that recruitment is highly informal, consistent with a secondary labour market. The vast majority of respondents (over 90 per cent) obtained their job via a personal approach, either being asked to work, or asking for work. This strongly contrasts with the very formal processes that apply for appointment to ongoing and in many cases, fixed term academic positions, consistent with permanent academics being in a form of internal labour market. Informal, localised and often 'sponsored' recruitment has implications for casual academic staff and how they are assisted with teaching and career opportunities.

The survey investigated whether respondents had access to induction, professional development, attended course meetings, belonged to a university committee, or attended department or faculty meetings. The results are shown in Table 5. Importantly, access to induction and professional development are key quality assurance activities from a university standpoint, providing the means of ensuring consistency of standards of teaching and 
expectations. The survey asked, in each case, if respondents had access to, or took part in these activities, and if so was it on an unpaid, fully paid or part paid basis. The results suggested that casuals were not being treated as an entry level into academia but rather as a secondary labour market. In every case the majority of respondents either had an unpaid provision or no provision at all. A third of respondents had not taken part in any induction or professional development at their university suggesting that many casual academics were not getting access to the most basic of information and support necessary to perform their jobs, and were missing out on career support that could assist with entry into a continuing position. Further, the finding that 47 per cent of respondents were attending course meetings, but doing so unpaid, showed the willingness of casual academic staff to engage in activities that are of benefit for their students, even if it meant doing so in their own time.

\section{Table 5 here}

If casual employment represented entry to the academic labour market, casuals would be similar to permanent academics in showing high internal mobility and relatively low external mobility. Our data show great differences between casual academic staff and permanent academic staff in external mobility: 86 per cent of casuals agreed, and only 9 per cent disagreed, that they have career mobility between universities and other sectors. Amongst permanent academics, the ratios are 46 and 38 per cent respectively, suggesting a much lower level of external mobility. The high expectations of casuals that they could get jobs in other sectors compare with low expectations mentioned above of getting permanent academic jobs. Casual academic staff want entry and integration into academia but many see that they will 
not be able to get it because it is a separate labour market, and so they keep open their perceived options in other sectors.

\section{Size and segmentation by university type}

In policy discourse in Australia, discussion often moves below the broadest level of the university system as a whole, and the system is seen as being segmented by university 'type'. The needs and organisation of the nine long-established and wealthy, research-intensive Sandstone Universities are seen as vastly different to those of the Gumtree Universities established in the 1960s and 1970s, and the former institutes of technology (Unitech Universities) and other regional and urban New Universities, mainly established from colleges of advanced education in the early 1990s. It would be reasonable in that context to expect that, when it came to casual academic employment, university type might form one of the main delineations.

Table 6 calculates the proportions of academic staff employed on a casual basis, by headcount, using the contactable population of permanent academic staff and casual academic staff for each university, as provided by each university for the purposes of WCAU survey distribution. The statistics are detailed by university type in order to protect the privacy of the universities that participated in the survey.

Table 6 about here 
Unitech Universities have the highest proportions of academic staff employed on a casual basis, with some 66 per cent of all academic staff employed casually, as described in column

2. Whilst these calculations compare academic staff who are more likely to be full-time, with casual academic staff who may only teach a few hours a week, they nonetheless provide an important indication of the teaching effort across the university sector undertaken by hourly paid staff.

In column three of Table 6 the level of casualisation is calculated for teaching and research academic staff by eliminating research only academic staff from the denominator. The calculation uses data from the DIISTRE Higher Education Staff Statistics Collection (DIISRTE, 2012) to deduct the number of research only staff (those academic staff who undertake little or no teaching) from each university's academic population to determine the numbers of teaching and research academic staff. Sandstone Universities employ much higher proportions of research only academic staff, as these universities earn the greatest proportion of research grant income. Once research only staff are removed from the calculation casualisation levels for Sandstone Universities, Gumtree Universities and New Universities are similar. Unitech Universities, however, still have the highest proportions of casual academic staff.

\section{Segmentation by discipline}

We could not directly obtain data on casual density by other potential differentiators, but we do have other data on them. The survey asked respondents to provide information about the discipline in which they were employed, choosing from a thirteen category menu or by providing information in an 'other' category box. Where no information was provided by the 
respondent about their discipline, information from the sampling frame about the work unit/department, was used. In all, an academic discipline was ascertained for 95 per cent of respondents $(n=3008)$. The discipline break-down of respondents is reported in Table 7 . Column 1 reports the proportion of respondents in each discipline. Discipline categories were aggregated to five broad groupings: 35.0 per cent of respondents worked in 'all sciences', 15.6 per cent in medical and health sciences, 14.3 per cent in business and law, 7.9 per cent in education and 27.1 per cent in humanities, arts and social sciences (HASS).

Table 7 about here

Column 2 shows the median age of those respondents in each discipline and significant variation by discipline is apparent. Those in the sciences, particularly biological sciences and physical, chemical, mathematical and earth sciences, are much younger than the average and contrast with other disciplines such as education and performing and visual arts where the median age is much older.

Column 3 reports the gender composition of the discipline: disciplines with less than 45 per cent female are male dominated; those with 45- 55 per cent female are defined as gender balanced; and those with greater than 55 per cent female are female dominated. The very different age and gender profiles of each of the disciplines reveals the heterogeneity of the casual academic workforce and hints that academic discipline may segment this workforce. This idea is reinforced by data that follow. 


\section{Qualifications}

Some 16 per cent of the casual academic staff have a PhD. This compared to 80 per cent of the permanent academic staff in the WCAU survey. However, a further 37 per cent of casual academic staff were studying for a $\mathrm{PhD}$ (Table 8). There were minimal differences in $\mathrm{PhD}$ holding between types of university where respondents were employed, but more substantial differences between university types in terms of whether casual academic staff were concurrently studying for a PhD: over two-fifths in Gumtree and Sandstone Universities were studying for a $\mathrm{PhD}$, compared to a little over one quarter in New Universities. A much larger source of differentiation was discipline: the proportion of casual academic staff who held PhDs ranged from 29 per cent in the humanities and arts to just 10 per cent in IT and communication science. Similarly, the proportion of casual academic staff who were contemporaneously studying for a degree ranged from 63 per cent in biological sciences to 16 per cent in architecture and urban environment disciplines. The greater importance of discipline over university type probably reflects the fact that casuals have more mobility within disciplines between universities, than they have within universities between disciplines. Indeed one in five casuals surveyed worked at more than one university.

\section{Table 8 about here}

The earlier data on external mobility suggest that casual academic staff have more external mobility to the professions associated with their disciplines than they have between disciplines. At a discipline and university level, the role of external mobility is indicated in the column to the right of Table 8 , which shows the net mobility score (those agreeing, minus those disagreeing, that they have mobility with other sectors) by university type and discipline. There are small, albeit significant differences between university types: Sandstone, 
Unitech and New Universities have net mobility scores around +77 to +78 , compared to +81 for Gumtrees. But discipline differences are substantial, with net mobility ranging from +87 in law and related areas, to +65 in humanities and arts. The latter is a particular problem area, as amongst permanent academic staff the net external mobility score is also the lowest, at -27 , in the humanities and arts: permanent academic staff find it hard to move out and, as we see later, this in turn makes it hardest to get in for casual academic staff, who in turn have the most limited external opportunities as well. Thus mobility differences differentially affect the opportunities available to casuals in various disciplines. External mobility tends to be lower in disciplines where a higher proportion of casuals hold $\mathrm{PhDs}(\mathrm{r}=-.87)$.

\section{Career satisfaction}

In order to determine how satisfied respondents were with their career opportunities at their university and across the sector, the following questions' responses were summed:

- 'I am satisfied with my career opportunities at this university' (5 point scale, strongly disagree to strongly agree)

- 'I am satisfied with my career opportunities in the university sector as a whole' (5 point scale, strongly disagree to strongly agree)

- 'My satisfaction with my career prospects' (3 point scale, gone up, stayed the same, gone down in the last 2 years).

The response order was reversed for the third question 'my satisfaction with my career prospects' to ensure that all the least satisfied and 'disagree' responses were aligned such that the lowest scores reflected the greatest levels of dissatisfaction with career opportunity, and 
the highest scores reflected the highest levels of satisfaction with career opportunity. The results for the first two questions were re-coded to add 'strongly disagree' and 'somewhat disagree' to form one point, and 'somewhat agree' and 'strongly agree' to form three. Combined these three questions formed an index that ranged from 3 points to 9 points as follows;

- $\quad$ 8-9 points - high levels of satisfaction (agreed with at least 2 statements)

- 5-7 points - medium levels of satisfaction

- 3-4 points - low levels of satisfaction (disagreed with at least 2 statements).

When combined, the index comprising these questions had an acceptable Cronbach alpha score of 0.719. Over a third of respondents had high levels of career satisfaction, and just under a third had low levels of career satisfaction.

This summary career satisfaction variable examining assessment of career opportunities was analysed by gender, university type, $\mathrm{PhD}$ status, casual type, and discipline to see if these groups varied in their satisfaction levels. These results are reported in Table 9. It can be seen that the groups that were most dissatisfied with their career opportunities are those with PhDs, those working in humanities and arts, and performing arts. On the other hand, casuals by choice, retirees and those working in the medical and health sciences discipline had high levels of career satisfaction.

The key feature of Table 9 is that, once again, discipline is a far stronger predictor than university type of the dependent variable - in this case, career satisfaction. In disciplines such as law and education, career satisfaction was roughly twice that in humanities and arts. Career satisfaction was also low in social sciences (where external mobility was low) and performing arts (an area where opportunities in the external labour market are likely to be 
irregular and poorly remunerated). Differences between university types were far smaller, with all securing percentages for the 'higher' career satisfaction group in the 30s.

\section{Table 9 about here}

\section{The frustrated academic index}

The WCAU survey asked respondents where they would 'like' to be in five years time, followed by where they 'expect' to be in five years time. The options offered in each case were as follows:

- Employed as a sessional/casual academic

- Employed as an academic in a continuing position

- Employed outside of the university sector

- Retired, not working

- Other including an option for comments.

The frustrated academic index reports the proportion of respondents who would like to be an academic in five years time, but expect that they will be in one of the other four categories. The question assessed aspiration and expectation, and for those whose aspiration to be a continuing academic was not matched by their expectation, it represented a measure of frustrated ambition. This draws our attention closer to those casual academic staff for whom casual academic employment is taken either as a means to a more secure academic position, or in the absence of a more secure academic position.

Overall, around half of all casuals aspiring to an academic position are 'frustrated academics' - they want to be academics in five years time, but do not expect to be. This 
reinforces the evidence that casual employment does not represent an entry level into the academic workforce. Rather, it is a separate, insecure secondary labour market. Importantly, as we have seen, this secondary labour market has segmentation within it.

The gap between aspiration and expectation, the 'frustrated academic index', shown in Figure 2, varies quite considerably between a range of categories such as gender, university type, qualification, and academic discipline. The graph shows that those who finished their $\mathrm{PhD}$ more than two years ago are the most frustrated. High levels of frustration were also found amongst those working in the humanities, arts and social sciences discipline, women generally, women employed at a Sandstone University, and those who held a $\mathrm{PhD}$. By contrast, those working in the business and law disciplines had much lower than average levels of frustration, highlighting, again, the diversity across the casual academic labour market, and the diversity in the composition of the various discipline-based labour markets. Low levels of frustrated academics were also found in the disciplines of engineering and business and law. Both of these disciplines are associated with professions which offer qualified individuals a range of career options outside of the university sector.

\section{Figure 2 here}

\section{Discussion and conclusion}

The picture that emerges of casual academic employment in universities is a secondary labour market that is segmented from the principal labour market and which, itself, comprises a substantial number of segments. Casual academic employment is not the entry level to an internal labour market of more secure, permanent employment. While the characteristics of the casual labour market are gendered, the principal lines of segmentation appear to be based 
on discipline rather than university type. Each discipline almost has its own casual labour segment. They differ from each other in terms of their openness to external mobility, and hence the availability of alternative opportunities. Where outside opportunities are less liberal, disciplines are able to take advantage of highly qualified individuals who are employed on casual contracts and who become frustrated at the difficulty of obtaining entry into the internal academic labour market, as the supply of casual staff in those disciplines exceeds limited demand. Casual academic staff in disciplines with greater external mobility are less frustrated and tend to be less qualified.

Across the thirteen designated academic disciplines significant variation by median age, gender composition and job and career satisfaction, and frustrated academic index levels were found. In particular, those in the humanities and arts, and performing and visual arts, were found to have very low levels of job and career satisfaction and very high levels of frustration. In contrast, the academic disciplines where there is mobility into an external, non-academic labour market, for example, engineering and technology, and business and law, showed high levels of job and career satisfaction, reflecting the greater range of opportunities available to those qualified in these fields.

This is not to deny that university type had a role in segmentation. For example, Unitech Universities had the highest proportions of their overall academic workforce employed on a casual basis, with the other three university groupings employing similar proportions once the research component of the academic workforce was taken into account. Sandstone Universities had a higher proportion of frustrated academics - but not as high as the rate amongst academics in the humanities, arts and other social sciences. Overall, then, discipline appeared more important than university type in creating labour market segments for casual academic staff. 
Furthermore, the casual academic labour market appears to be segmented from the permanent academic labour market. Evidence for this is found in the poor provision of job and career supports, and the high levels of frustrated academics, particularly among some groups. The fact that so many aspiring academics are very pessimistic about their chances of securing an academic position suggests that there are high barriers to entry. Their pessimism is reinforced by the international nature and dimension of the academic labour market.

Our study reveals far more about the casual academic workforce than has previously been known. Significant differences between the permanent academic workforce and the casual academic workforce are revealed in relation to age, gender, and $\mathrm{PhD}$ qualification levels. There were gendered patterns in discipline profiles, $\mathrm{PhD}$ study, main sources of income, and access to facilities. The casual academic workforce is also very different to the wider casual workforce, with an older age profile, a function of the higher qualification levels of this cohort, but an even larger age gap to the permanent academic workforce. For a majority of casual academic staff, casual work is part of their training and preparation for what they hope will be a more secure academic position. Yet many casuals do not see this door as opening to them. PhD study provides training in research, but not teaching, yet at least as much of a teaching and research academic's time will be spent teaching, as undergoing research. Thus what happens during this period of casual employment, particularly for those who are also undertaking $\mathrm{PhD}$ study, is critical to both their future, and to the future academic workforce. 


\section{Appendix 1}

\section{Marginson's typology of Universities (adapted)}

\begin{tabular}{|c|c|c|c|}
\hline $\begin{array}{c}\text { Sandstone } \\
\text { Universities } \\
\text { (also the Group of 8) }\end{array}$ & $\begin{array}{c}\text { Gumtree } \\
\text { Universities }\end{array}$ & $\begin{array}{c}\text { Unitech Universities } \\
\text { (also the ATN } \\
\text { grouping) }\end{array}$ & New Universities \\
\hline SANDSTONE (6) & $\begin{array}{l}\text { Griffith } \\
\text { University }\end{array}$ & $\begin{array}{l}\text { University of } \\
\text { Technology Sydeny }\end{array}$ & $\begin{array}{l}\text { Edith Cowan } \\
\text { University }\end{array}$ \\
\hline $\begin{array}{l}\text { University of } \\
\text { Queensland }\end{array}$ & $\begin{array}{l}\text { Newcastle } \\
\text { University }\end{array}$ & $\begin{array}{l}\text { Queensland } \\
\text { University of } \\
\text { Technology }\end{array}$ & $\begin{array}{l}\text { Central Queensland } \\
\text { University }\end{array}$ \\
\hline $\begin{array}{l}\text { University of Western } \\
\text { Australia }\end{array}$ & $\begin{array}{l}\text { Flinders } \\
\text { University }\end{array}$ & RMIT University & $\begin{array}{l}\text { Southern Cross } \\
\text { University }\end{array}$ \\
\hline $\begin{array}{l}\text { University of } \\
\text { Adelaide }\end{array}$ & $\begin{array}{l}\text { James Cook } \\
\text { University }\end{array}$ & Curtin University & $\begin{array}{l}\text { University of } \\
\text { Western Sydney }\end{array}$ \\
\hline $\begin{array}{l}\text { University of } \\
\text { Tasmania* }\end{array}$ & $\begin{array}{l}\text { La Trobe } \\
\text { University }\end{array}$ & $\begin{array}{l}\text { University of South } \\
\text { Australia }\end{array}$ & $\begin{array}{l}\text { Charles Sturt } \\
\text { University }\end{array}$ \\
\hline $\begin{array}{l}\text { University of } \\
\text { Melbourne }\end{array}$ & $\begin{array}{l}\text { Macquarie } \\
\text { University }\end{array}$ & & Victoria University \\
\hline University of Sydney & $\begin{array}{l}\text { Wollongong } \\
\text { University }\end{array}$ & & $\begin{array}{l}\text { University of } \\
\text { Southern Queensland }\end{array}$ \\
\hline REDBRICKS (3) & $\begin{array}{l}\text { Murdoch } \\
\text { University }\end{array}$ & & $\begin{array}{l}\text { University of } \\
\text { Canberra }\end{array}$ \\
\hline $\begin{array}{l}\text { Australian National } \\
\text { University }\end{array}$ & $\begin{array}{l}\text { University of } \\
\text { New England }\end{array}$ & & $\begin{array}{l}\text { Australian Catholic } \\
\text { University }\end{array}$ \\
\hline Monash University & & & $\begin{array}{l}\text { Charles Darwin } \\
\text { University }\end{array}$ \\
\hline \multirow[t]{4}{*}{ University of NSW } & & & $\begin{array}{l}\text { Swinburne } \\
\text { University }\end{array}$ \\
\hline & & & $\begin{array}{l}\text { University of } \\
\text { Ballarat }\end{array}$ \\
\hline & & & $\begin{array}{l}\text { University of the } \\
\text { Sunshine Coast }\end{array}$ \\
\hline & & & Deakin University \\
\hline
\end{tabular}

Source: Marginson and Considine (2000: 189-190)

* Not in "Group of 8"

Note: 19 of the 37 above universities were included in the WCAU study. 


\section{References}

Australian Bureau of Statistics (2011) Employee Earnings, Benefits and Trade Union Membership, Cat. 6310.0. Canberra.

Australian Bureau of Statistics (2012) Australian Labour Market Statistics, Cat. 6105.0. Canberra.

Baranay, I (2007) 'The academic underclass' Griffith Review, 11 (Feb) pp. 39-49.

Bauder, H (2006) 'The Segmentation of Academic Labour: A Canadian Example' ACME: An International E-Journal for Critical Geographies, 4 (2) pp. 228-239.

Becher, T (1994) 'The significance of disciplinary differences' Studies in Higher Education, 19 (2) pp. 151-162.

Bexley, E, James, R \& Arkoudis, S (2011) The Australian academic profession in transition. Centre for the Study of Higher Education. Melbourne: September 2011.

Blackmore, J (2002) 'Globalisation and the Restructuring of Higher Education for New Knowledge Economies: New Dangers or Old Habits Troubling Gender Equity Work in Universities?' Higher Education Quarterly, 56 (4) pp. pp 419-441.

Bradley, D (2008) Review of Australian Higher Education, Canberra, Commonwealth of Australia

Brand, T (2013) 'Foreword'. in F Beaton \& A Gilbert. Developing Effective Part-Time Teachers in Higher Education. Routledge, London.

Brown, T, Goodman, J \& Yasukawa, K (2006) Getting the best of you for nothing: Casual voices in the Australian Academy, NTEU, South Melbourne.

Bryson, C \& Blackwell, R (2006) 'Managing temporary workers in higher education: Still at the margin?' Personnel Review, 35 (2) pp. 207-224.

Churchman, D (2005) 'You will do: The construction of meaning and identity by sessional academic staff'. ANZCA Conference, Christchurch, New Zealand.

Coates, H \& Goedegebuure, L (2010) The Real Academic Revolution. Research Briefing. LHMartin Institute, Melbourne

Curtis, J \& Jacobe, M (2006) AAUP Contingent Faculty Index. AAUP Policy documents and reports, AAUP, Washington DC.

DIISRTE (2012) Staff 2012 Selected Higher Education Statistics. DIISRTE. Canberra. $<$ http://www.innovation.gov.au/HigherEducation/HigherEducationStatistics/StatisticsPublicat ions/Pages/Staff.aspx\%3E.

Dobbie, D \& Robinson, D (2008) 'Reorganising higher education in the United States and Canada' Labor Studies Journal, 33 (2) pp. 117-140.

Doeringer, P \& Piore, M (1971) Internal Labour Markets and Manpower Analysis, Heath Lexington Books, Lexington.

Finnegan, D (1993) 'Segmentation in the Academic Labor Market' The Journal of Higher Education, 64 (6) pp. 621-656.

Gappa, J \& Leslie, D (1993) The invisible faculty: Improving the status of part timers in higher education, Jossey-Bass, San Francisco.

Gottschalk, L \& McEachern, S (2007) Casual and sessional employment: Motivation and work/life balance, School of Business, University of Ballarat, Ballarat.

Grimshaw, D, Ward, K, Rubery, J \& Benyon, H (2001) 'Organisations and the Transformation of the Internal Labour Market in the UK' Work, Employment and Society, 15 (1) pp. 25-54.

Hood, C (1991) 'A Public Management for all Seasons' Public Administration, 69 (1) pp. 3-19.

Hugo, G (2008) The demographic outlook for Australian Universities' academic staff. Occassional Paper, CHASS, Canberra.

Husbands, C \& Davies, A (2000) 'The teaching roles, institutional locations, and terms and conditions of employment of part-time teachers in UK Higher Education' Journal of Further and Higher Education, 24 (3) pp. 337-362.

Junor, A (2004) 'Casual University Work: Choice, Risk, Inequity and the Case for Regulation' The Economic and Labour Relations Review, 14 (2) pp. 276-304.

Kimber, M (2003) 'The tenured 'core' and the tenuous 'periphery': The casualisation of academic work in Universities' Journal of Higher Education Policy and Management, 25 (1) pp. 41-50. 
Marginson, S \& Considine, M (2000) The Enterprise University: Power, Governance and Reinvention in Australia, Cambridge University Press, Cambridge.

Moore, H, Acosta, K, Perry, G \& Edwards, C (2010) 'Splitting the Academy: The emotions of intersectionality at work' The Sociological Quarterly, 51 pp. 179-204.

Morehead, A, Steele, M, Alexander, M, Stephen, K \& Duffin, L (1997) Changes at Work: The 1995 Australian Workplace Industrial Relations Survey, Wesley Longman, Melbourne.

NTEU (2008) 'Fighting for the rights of casual and sessional staff' Advocate, 15 (2).

Peck, J (1996) Workplace: The Social Regulation of Labour Markets, New York, The Guilford Press

Percy, A, Scoufis, M, Parry, M, Goody, S, Hicks, A, Macdonald, I, Martinez, K, Szorenyi-Reischl, N, Ryan, Y, Wills, S \& Sheridan, L (2008) The RED Report, ALTC, Sydney.

Pocock, B, Buchanan, J \& Campbell, I (2004) Securing quality employment: Policy options for casual and part time workers in Australia, Chifley Research Centre, Adelaide, Chifley Research Centre, 67.

Rajagopal, I \& Lin, Z (1996) 'Hidden Careerists in Canadian Universities' Higher Education, 32 (3) pp. 247-266.

Robinson, D (2006) The Status of Higher Education Teaching Personnel in Australia, Canada, New Zealand, the United Kingdom and the United States, Report prepared for Education International, Brussels, March 2006

Roemer, R \& Schnitz, J (1982) 'Academic Employment as Day Labor' The Journal of Higher Education, 53 (5) pp. 514-531.

Rosenblum, G \& Rosenblum, B (1997) 'Changing Patterns of Job Entitlements in Academe: Labour Market Entry' The Review of Higher Education, 21 (1) pp. 1-18.

Schuster, J \& Finkelstein, M (2006) 'On the brink: Assessing the Status of the American Faculty' Centre for Studies in Higher Education,Occassional Paper Series: CSHE UC Berkley.

Slaughter, S \& Rhoades, G (2004) Academic Capitalism and the New Economy, The Johns Hopkins University Press, Baltimore and London.

Strachan, G, Troup, C, Peetz, D, Whitehouse, G, Broadbent, K \& Bailey, J (2012) Work and Careers in Australian Universities: Report on Employee Survey Griffith University, Centre for Work Organisation and Wellbeing.

Torens, N (1993) 'The temporal dimensions of gender inequality in academia' Higher Education, 25 pp. 439-455. 
Table 1: Proportion of academic staff employed as casual, full time equivalent (FTE) figures, selected years

\begin{tabular}{|c|c|c|c|}
\hline Year & $\begin{array}{c}\text { Non-casual } \\
\text { academic FTE } \\
\text { (1) }\end{array}$ & $\begin{array}{c}\text { Casual } \\
\text { academic FTE } \\
(2)\end{array}$ & $\begin{array}{c}\text { Proportion of academic staff } \\
\text { employed as casual FTE }(\%) \\
2 /(1+2)\end{array}$ \\
\hline 1990 & 26530 & 3259 & 11.0 \\
\hline 1994 & 30276 & 5497 & 15.3 \\
\hline 1996 & 31256 & 6095 & 16.3 \\
\hline 1998 & 30148 & 6306 & 17.3 \\
\hline 2000 & 29893 & 7106 & 19.2 \\
\hline 2002 & 30997 & 7862 & 20.2 \\
\hline 2004 & 33043 & 8136 & 19.8 \\
\hline 2005 & 34227 & 8028 & 19.0 \\
\hline 2006 & 35151 & 8353 & 19.2 \\
\hline 2007 & 36592 & 8490 & 19.0 \\
\hline 2008 & 37522 & 9086 & 19.5 \\
\hline 2009 & 38965 & 9968 & 20.4 \\
\hline 2010 & 40100 & 10691 & 21.0 \\
\hline 2011 & 41090 & 11429 & 21.7 \\
\hline
\end{tabular}

Source: DEEWR, DEST, DIISRTE Selected Higher Education Staff Statistics, Table 1.7, Appendix 1.5, various years,

Table 2: Average response rates by university type, WCAU survey 2011

\begin{tabular}{|l|c|c|c|c|c|}
\hline & $\begin{array}{c}\text { Response } \\
\text { rate } \\
\text { \% }\end{array}$ & $\begin{array}{c}\text { No. of } \\
\text { universities } \\
\text { in sample }\end{array}$ & $\begin{array}{c}\text { No. in } \\
\text { sample } \\
\text { (n) }\end{array}$ & $\begin{array}{c}\text { Population } \\
(\mathbf{n})\end{array}$ & $\begin{array}{c}\text { Proportion } \\
\text { of sample } \\
\text { \% }\end{array}$ \\
\hline Sandstone & 16.5 & 5 & 1368 & 8297 & 43.3 \\
\hline Gumtree & 11.4 & 4 & 600 & 5254 & 19.0 \\
\hline Unitech & 9.7 & 2 & 506 & 5222 & 16.0 \\
\hline New & 13.9 & 8 & 686 & 4947 & 21.7 \\
\hline Total & $\mathbf{1 3 . 3}$ & $\mathbf{1 9}$ & $\mathbf{3 1 6 0}$ & $\mathbf{2 3 7 2 0}$ & $\mathbf{1 0 0}$ \\
\hline
\end{tabular}

Source: WCAU casual academic staff survey 2011 
Table 3: Demographic aspects - casual academic staff and permanent academic staff, WCAU Survey 2011

\begin{tabular}{|l|c|c|}
\hline & $\begin{array}{c}\text { Casual academic } \\
\text { staff survey } \\
\%\end{array}$ & $\begin{array}{c}\text { Permanent } \\
\text { academic staff } \\
\text { survey } \\
\mathbf{\%}\end{array}$ \\
\hline Proportion female & 57 & 51 \\
\hline Median age & 36 years & 46 years \\
\hline Proportion born overseas & 40 & 42 \\
\hline Median period of employment & 3 years & 5 years \\
\hline
\end{tabular}

Source: WCAU academic staff and casual academic staff survey 2011

Figure 1: Age profile of permanent academic staff and casual academic staff by gender (proportion of sample at each age range)

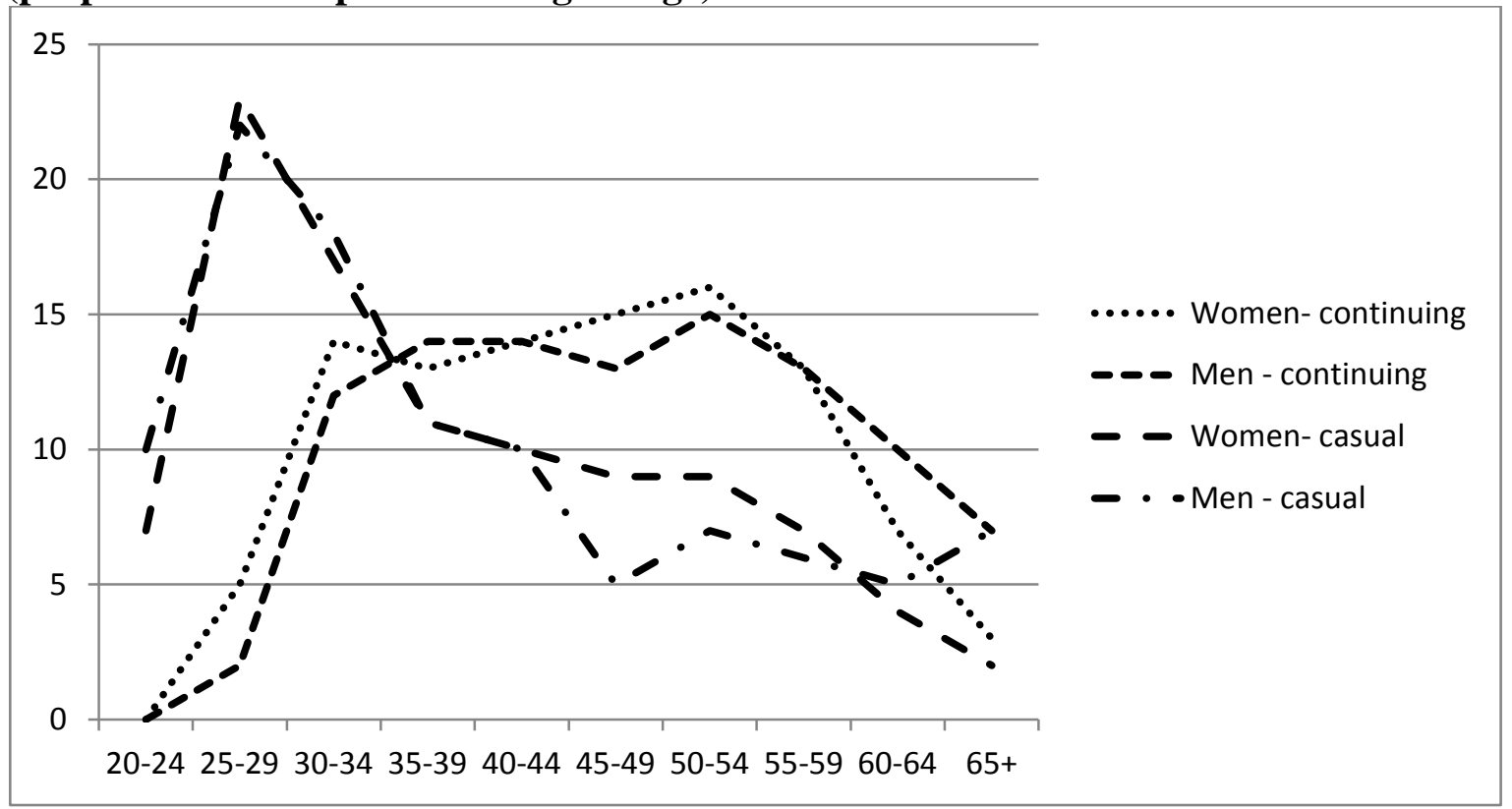

Source: WCAU academic staff and casual academic staff survey 2011 
Table 4: A typology of casual academic staff by gender, WCAU survey 2011

\begin{tabular}{|l|c|c|c|}
\hline & $\begin{array}{c}\text { Men } \\
\text { \% }\end{array}$ & $\begin{array}{c}\text { Women } \\
\text { \% }\end{array}$ & $\begin{array}{c}\text { Total } \\
\text { \% }\end{array}$ \\
\hline $\begin{array}{l}\text { Aspiring academic - aspires to an } \\
\text { academic position }\end{array}$ & 54 & 58 & 56 \\
\hline $\begin{array}{l}\text { Externally oriented - is oriented toward } \\
\text { work outside the university sector either } \\
\text { now or in the future }\end{array}$ & 25 & 24 & 24 \\
\hline $\begin{array}{l}\text { Casual by 'choice' - would like to be in } \\
\text { casual/sessional position in five years time } \\
\text { (but not retiring) }\end{array}$ & 12 & 12 & 12 \\
\hline $\begin{array}{l}\text { Retiree/retired - currently depends on } \\
\text { pension as main source of income, over 65, } \\
\text { or would like to be retired in five years }\end{array}$ & 9 & 6 & 7 \\
\hline Total & $\mathbf{1 0 0}$ & $\mathbf{1 0 0}$ & $\mathbf{1 0 0}$ \\
\hline
\end{tabular}

(a) Note: excludes missing data. Source: WCAU casual academic staff survey 2011

Table 5: Casual academic staff access to job and career support

\begin{tabular}{|l|c|c|c|c|c|}
\hline & Have you ever taken \\
part in the following? & $\begin{array}{c}\text { No } \\
\text { \% }\end{array}$ & $\begin{array}{c}\text { Unpaid } \\
\text { \% }\end{array}$ & $\begin{array}{c}\text { Partly } \\
\text { paid } \\
\text { \% }\end{array}$ & $\begin{array}{c}\text { Fully paid } \\
\%\end{array}$ & Total \\
\hline Induction & 32.9 & 24.8 & 2.6 & 39.6 & 100.0 \\
\hline $\begin{array}{l}\text { Professional } \\
\text { development, training }\end{array}$ & 36.4 & 27.6 & 4.5 & 31.5 & 100.0 \\
\hline Attend course meetings & 17.0 & 46.8 & 7.2 & 29.0 & 100.0 \\
\hline $\begin{array}{l}\text { Attend general } \\
\text { school/dept meetings }\end{array}$ & 47.3 & 31.8 & 3.2 & 17.7 & 100.0 \\
\hline
\end{tabular}

Source: WCAU casual academic staff survey 2011 
Table 6: Proportion of academic staff employed on a casual basis, headcount, by university type, WCAU survey 2011

\begin{tabular}{|l|c|c|c|}
\hline University type & $\begin{array}{c}\text { (1) } \\
\text { Number of } \\
\text { universities in the } \\
\text { survey }\end{array}$ & $\begin{array}{c}\text { (2) } \\
\text { Average proportion } \\
\text { of all academic staff } \\
\text { employed on a } \\
\text { casual basis } \\
\text { (headcount) } \\
\text { \% }\end{array}$ & $\begin{array}{c}\text { (3) } \\
\text { Average proportion } \\
\text { of all T\&R academic } \\
\text { staff only employed } \\
\text { on a casual basis } \\
\text { (headcount) } \\
\text { \% }\end{array}$ \\
\hline Unitech & 2 & 66 & 72 \\
\hline Gumtree & 4 & 47 & 54 \\
\hline Sandstone & 5 & 37 & 51 \\
\hline New & 8 & 44 & 49 \\
\hline Total - average & $\mathbf{1 9}$ & $\mathbf{4 9}$ & $\mathbf{5 3}$ \\
\hline
\end{tabular}

Source: WCAU academic staff and casual academic staff survey 2011, DIISTRE HES staff statistics 2012 
Table 7: Academic discipline of casual academic staff, WCAU survey 2011

\begin{tabular}{|c|c|c|c|}
\hline Academic discipline & $\begin{array}{c}\text { Proportion } \\
\text { of sample \% }\end{array}$ & $\begin{array}{l}\text { Median } \\
\text { age in } \\
\text { discipline }\end{array}$ & $\begin{array}{l}\text { Women in } \\
\text { discipline } \\
\text { casual \% }\end{array}$ \\
\hline ALL SCIENCES & 35.0 & - & - \\
\hline $\begin{array}{l}\text { Physical, Chemical, Mathematical and } \\
\text { Earth Sciences }\end{array}$ & 7.9 & 28 & $43.9(M)$ \\
\hline $\begin{array}{l}\text { Biological, Behavioural and Cognitive } \\
\text { Sciences }\end{array}$ & 9.3 & 28 & $69.3(F)$ \\
\hline $\begin{array}{l}\text { Information, Computing and } \\
\text { Communication Sciences }\end{array}$ & 4.2 & 32 & $27.2(M)$ \\
\hline Engineering and Technology & 9.1 & 29 & $21.8(M)$ \\
\hline $\begin{array}{l}\text { Architecture, Urban Environment and } \\
\text { Building }\end{array}$ & 4.5 & 39 & $49.3(B)$ \\
\hline $\begin{array}{l}\text { MEDICAL AND HEALTH } \\
\text { SCIENCES }\end{array}$ & 15.6 & 37 & $67.0(F)$ \\
\hline BUSINESS AND LAW & 14.3 & - & $49.1(\mathrm{~B})$ \\
\hline Law, Justice and Law Enforcement & 1.7 & 37 & $72.0(F)$ \\
\hline Business, Economics and Tourism & 12.6 & 39 & $46.3(B)$ \\
\hline EDUCATION & 7.9 & 52 & $75.7(F)$ \\
\hline HASS & 27.1 & - & - \\
\hline Performing and Visual Arts & 3.4 & 43 & $55.4(F)$ \\
\hline Humanities and Arts & 13.2 & 39 & $67.6(F)$ \\
\hline Social Sciences & 8.6 & 35 & $62.3(F)$ \\
\hline Other & 1.9 & 43 & $64.9(F)$ \\
\hline TOTAL & 100 & 36 & 56.2 \\
\hline
\end{tabular}

*Note: $\mathrm{M}=$ Male dominated discipline, $\mathrm{F}=$ Female dominated discipline, $\mathrm{B}=$ Gender balanced discipline Source: WCAU casual academic staff survey 2011 
Table 8: Proportion of respondents studying for a $\mathrm{PhD}$ qualification, and external mobility score, by University type, WCAU survey 2011

\begin{tabular}{|c|c|c|c|}
\hline & \multicolumn{2}{|c|}{$\begin{array}{l}\text { PhD status, proportion of } \\
\text { respondents: }\end{array}$} & \multirow{2}{*}{$\begin{array}{l}\text { Mobility: } \\
\text { Net external } \\
\text { mobility score } \\
\text { (a) }\end{array}$} \\
\hline & $\begin{array}{c}\text { With a PhD } \\
\%\end{array}$ & $\begin{array}{c}\text { Currently } \\
\text { studying for a } \\
\text { PhD } \\
\%\end{array}$ & \\
\hline Sandstone & 16.8 & 42.5 & 77.6 \\
\hline Gumtree & 16.1 & 42.8 & 80.8 \\
\hline Unitech & 16.8 & 32.7 & 77.8 \\
\hline New & 14.5 & 26.5 & 76.5 \\
\hline Overall sample & 16.2 & 37.5 & 77.2 \\
\hline \multicolumn{4}{|l|}{ Discipline } \\
\hline $\begin{array}{l}\text { Law, Justice and Law } \\
\text { Enforcement }\end{array}$ & 10.0 & 34.0 & 87.2 \\
\hline Education & 14.6 & 21.4 & 86.9 \\
\hline $\begin{array}{l}\text { Information, Computing and } \\
\text { Communication Sciences }\end{array}$ & 9.8 & 38.7 & 86.6 \\
\hline Other & 11.1 & 14.3 & 86.5 \\
\hline $\begin{array}{l}\text { Architecture, urban } \\
\text { environment, building, } \\
\text { agriculture }\end{array}$ & 11.9 & 16.2 & 82.0 \\
\hline Medical and health sciences & 15.5 & 27.9 & 81.1 \\
\hline Performing and Visual Arts & 15.2 & 27.7 & 80.9 \\
\hline $\begin{array}{l}\text { Biological, Behavioural and } \\
\text { Cognitive Sciences }\end{array}$ & 14.1 & 63.1 & 80.8 \\
\hline Engineering and Technology & 11.8 & 54.9 & 79.8 \\
\hline $\begin{array}{l}\text { Business, Economics and } \\
\text { Tourism }\end{array}$ & 13.0 & 31.7 & 75.5 \\
\hline Social Sciences & 19.3 & 54.6 & 71.9 \\
\hline $\begin{array}{l}\text { Physical, Chemical, } \\
\text { Mathematical and Earth } \\
\text { Sciences }\end{array}$ & 19.2 & 50.0 & 69.2 \\
\hline Humanities and Arts & 28.7 & 40.5 & 65.0 \\
\hline
\end{tabular}

(a) Net external mobility score is the proportion agreeing with the statement 'I have career mobility between universities and other sectors', minus the proportion disagreeing.

Source: WCAU casual academic staff survey 2011 
Table 9: Career satisfaction by gender, university type, $\mathrm{PhD}$, casual type and academic discipline, WCAU survey 2011

\begin{tabular}{|c|c|c|}
\hline $\begin{array}{l}\text { Assessment of career opportunity } \\
\text { Category }\end{array}$ & $\begin{array}{l}\text { Lower career } \\
\text { satisfaction } \\
\% \text { of category } \\
\end{array}$ & $\begin{array}{c}\text { Higher career } \\
\text { satisfaction } \\
\% \text { of category }\end{array}$ \\
\hline \multicolumn{3}{|l|}{ GENDER } \\
\hline Men & 29.7 & 33.4 \\
\hline Women & 29.7 & 35.7 \\
\hline \multicolumn{3}{|l|}{ UNIVERSITY TYPE } \\
\hline Sandstone & 30.9 & 33.3 \\
\hline Gumtree & 29.3 & 30.5 \\
\hline Unitech & 27.6 & 35.6 \\
\hline New & 29.1 & 39.2 \\
\hline Chi square significance $(a)$ & & .004 \\
\hline \multicolumn{3}{|l|}{ PHD STATUS } \\
\hline PhD holder & 50.5 & 17.9 \\
\hline Does not hold $\mathrm{PhD}$ & 25.9 & 37.1 \\
\hline Chi square significance & & .000 \\
\hline \multicolumn{3}{|l|}{ CASUAL TYPE } \\
\hline Casual type - aspiring academic & 32.3 & 33.4 \\
\hline Casual type - external focus & 32.0 & 28.9 \\
\hline Casual type - casual by choice & 18.9 & 45.7 \\
\hline Casual type - retiree & 20.0 & 44.1 \\
\hline Chi square significance & & .000 \\
\hline \multicolumn{3}{|l|}{ DISCIPLINE } \\
\hline Law, Justice and Law Enforcement & 19.5 & 36.6 \\
\hline Education & 26.6 & 38.8 \\
\hline $\begin{array}{l}\text { Information, Computing and Communication } \\
\text { Sciences }\end{array}$ & 24.5 & 34.3 \\
\hline Other & 20.0 & 36.7 \\
\hline $\begin{array}{l}\text { Architecture, Urban Environment, Building and } \\
\text { Agriculture }\end{array}$ & 20.0 & 40.9 \\
\hline Medical and Health Sciences & 19.1 & 42.7 \\
\hline Performing and Visual Arts & 47.3 & 26.4 \\
\hline Biological, Behavioural and Cognitive Sciences & 24.1 & 32.9 \\
\hline Engineering and Technology & 22.7 & 40.8 \\
\hline Business, Economics and Tourism & 24.0 & 39.0 \\
\hline Social Sciences & 39.7 & 24.4 \\
\hline $\begin{array}{l}\text { Physical, Chemical, Mathematical and Earth } \\
\text { Sciences }\end{array}$ & 24.6 & 41.2 \\
\hline Humanitites and Arts & 54.4 & 19.1 \\
\hline Chi square significance & & .000 \\
\hline Total & 29.7 & 34.5 \\
\hline
\end{tabular}

(a) Chi-squared significance refers to the group of cells in the topic immediately above. Source: WCAU casual academic staff survey 2011 
Figure 2: Frustrated academic index by selected categories, WCAU survey 2011

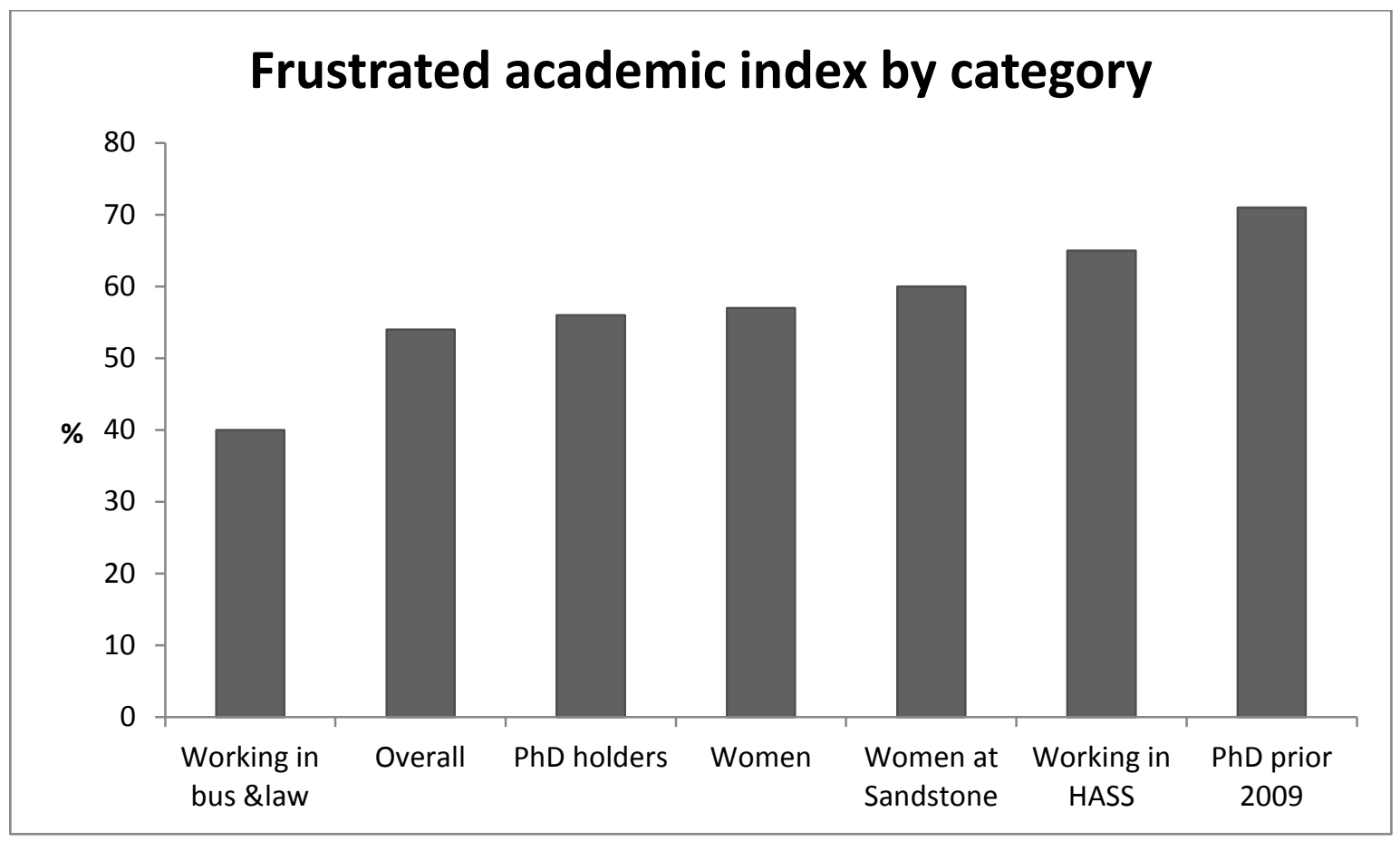

Source: WCAU casual academic staff survey 2011 